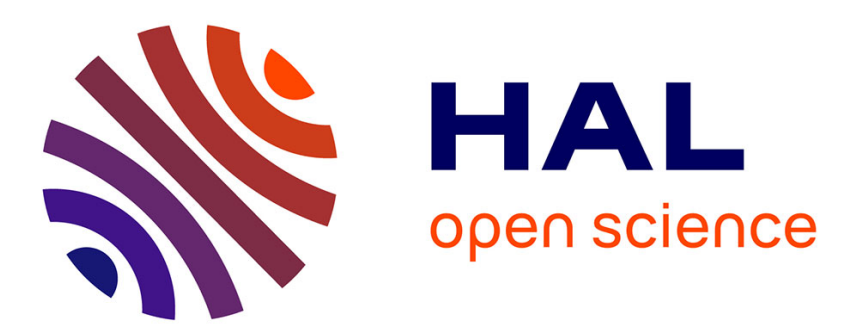

\title{
Fatty acid composition of muscle and adipose tissues of indigenous Caribbean goats under varying nutritional densities
}

Leticia L. Limea, Gisèle G. Alexandre, Valérie Berthelot

\section{- To cite this version:}

Leticia L. Limea, Gisèle G. Alexandre, Valérie Berthelot. Fatty acid composition of muscle and adipose tissues of indigenous Caribbean goats under varying nutritional densities. Journal of Animal Science, 2012, 90 (2), pp.605-615. 10.2527/jas.2010-3624 . hal-01001176

\section{HAL Id: hal-01001176 https://hal.science/hal-01001176}

Submitted on 28 May 2020

HAL is a multi-disciplinary open access archive for the deposit and dissemination of scientific research documents, whether they are published or not. The documents may come from teaching and research institutions in France or abroad, or from public or private research centers.
L'archive ouverte pluridisciplinaire HAL, est destinée au dépôt et à la diffusion de documents scientifiques de niveau recherche, publiés ou non, émanant des établissements d'enseignement et de recherche français ou étrangers, des laboratoires publics ou privés. 


\section{JOURNAL OF ANIMAL SCIENCE}

The Premier Journal and Leading Source of New Knowledge and Perspective in Animal Science

Fatty acid composition of muscle and adipose tissues of indigenous Caribbean goats under varying nutritional densities

L. Liméa, G. Alexandre and V. Berthelot

J ANIM SCI 2012, 90:605-615.

doi: $10.2527 /$ jas.2010-3624

The online version of this article, along with updated information and services, is located on the World Wide Web at:

http://www.journalofanimalscience.org/content/90/2/605 


\title{
Fatty acid composition of muscle and adipose tissues of indigenous Caribbean goats under varying nutritional densities ${ }^{1}$
}

\author{
L. Liméa, ${ }^{* 2}$ G. Alexandre, ${ }^{* 3,4}$ and V. Berthelot $\dagger^{3,4}$ \\ *INRA, UR143, Recherches Zootechniques, Centre Antilles-Guyane, F-97170, Petit-Bourg, Guadeloupe, France; \\ and †UMR INRA-AgroParisTech, Modélisation Systémique Appliquée aux Ruminants, \\ 16 rue Claude Bernard, F-75005, Paris, France
}

\begin{abstract}
The effects of a concentrate diet on growth, carcass fat, and fatty acid (FA) composition of muscle (supraspinatus), perirenal, and intermuscular adipose tissues of Creole goats $(\mathrm{n}=32)$ were evaluated. Goats were fed a tropical green forage Digitaria decumbens ad libitum with no concentrate (G0) or 1 of 3 levels of concentrate: 140 (G100), 240 (G200), and $340 \mathrm{~g} \cdot \mathrm{d}^{-1}$ (G300), respectively. Goats were slaughtered according to the standard procedure at the commercial $\mathrm{BW}$ (22 to $24 \mathrm{~kg}$ of BW). Goats fed the concentrate diets (G100, G200, and G300) had greater ADG $(P<$ $0.001)$, cold carcass weights $(P<0.001)$, and omental $(P<0.01)$, perirenal $(P<0.01)$, and intermuscular $(P<0.01)$ adipose tissues weights. Dietary intake of C18:0, C18:1n-9, C18:2n-6 increased as concen-
\end{abstract}

trate supplementation increased $(P<0.001)$, whereas C18:3n-3 intake was not affected $(P>0.05)$. Increased concentrate supplementation did not affect $(P>0.05)$ the proportion of MUFA in all tissues and had very little effect on SFA in perirenal tissue, but increased the PUFA proportion in muscle $(P<0.05)$. The major effect of feeding increased concentrate was an increase in n-6 PUFA proportions in all tissues $(P<0.001)$ and, surprisingly, a decrease in n-3 PUFA $(P<0.001)$. Focusing on FA, which are supposed to have a beneficial or an adverse effect on human health, feeding increased concentrate did not increase the content of any cholesterol-increasing SFA in meat, but increased the n-6/n-3 ratio above 4 when more than $240 \mathrm{~g}$ of concentrate was fed per day.

Key words: adipose tissue, concentrate, fatty acid, goat, muscle, tropical forage

(C)2012 American Society of Animal Science. All rights reserved.

J. Anim. Sci. 2012. 90:605-615 doi:10.2527/jas.2010-3624

\section{INTRODUCTION}

The consumption of fat in meat from ruminants has been associated with high-calorie intakes and fatty acid

\footnotetext{
${ }^{1}$ The valuable comments of editors and anonymous referees are acknowledged. The authors thank O. Coppry, R. Arquet, and F. Mounoussamy (INRA, Petit-Bourg, France) for their technical assistance, as well as T. Etienne, S. Calif, G. Saminadin (INRA, Petit-Bourg, France), and H. Albarello (INRA Agroparistech) for the laboratory analyses. This study was supported by the Region Guadeloupe and the European Community (Fonds Européen d'Orientation et de Garantie Agricole).

${ }^{2}$ The first author is the $\mathrm{PhD}$ student who was in charge of all field and laboratory measures, the constitution of the experimental database, and the literature review.

${ }^{3}$ These authors contributed equally to this study: G. Alexandre in the design of the experiment, growth and feeding measurements, and V. Berthelot in fatty acid determination and manuscript redaction. The 3 authors contributed equally to the data processing and to enriching the discussion.

${ }^{4}$ Corresponding author for all mailing and administrative considerations: gisele.alexandre@antilles.inra.fr; corresponding author for scientific discussion: valerie.berthelot@agroparistech.fr

Received October 22, 2010.

Accepted September 12, 2011.
}

(FA) profiles that are associated with health problems. To overcome this problem, ruminant meat producers need to focus on producing a leaner meat with decreased proportions of SFA, especially C14:0 and C16:0, and increased proportions of cis-MUFA and PUFA, especially long-chain PUFA of the n-3 series. The potential health benefits would be improved if trans-MUFA were reduced and CLA were increased, especially the C18:2cis-9, trans-11 isomer (Aurousseau et al., 2004). In this context, goat meat has an advantage over beef and lamb due to its low fat content (Webb and O'Neill, 2008) and a favorable FA composition of fat (Banskalieva et al., 2000).

Supplementing forage-feeding (FF) with concentrates $(\mathbf{C F})$ improved ADG of kids but also increased carcass fat content because of greater energy intakes (Ryan et al., 2007). It has been speculated that concentrate feeding might be associated with changes in the FA profile of muscle and fat due to the differences in the FA content and profile of feed ingredients. Meat from forage-fed ruminants has a greater n-3 PUFA content than that from concentrate-fed-ruminants, despite increased ruminal PUFA biohydrogenation in these 
Table 1. Ingredients, chemical composition, and fatty acid (FA) content of the different components of the diets

\begin{tabular}{|c|c|c|}
\hline Item & Tropical forage & Commercial pellet $^{1}$ \\
\hline $\mathrm{DM},{ }^{2} \%$ & 23.3 & 88.9 \\
\hline \multicolumn{3}{|c|}{ Chemical composition, ${ }^{2} \mathrm{~g} \cdot \mathrm{kg}^{-1}$ of DM } \\
\hline $\mathrm{CP}$ & 108 & 209 \\
\hline Ether extract & 14 & 25 \\
\hline $\mathrm{NDF}$ & 686 & 168 \\
\hline $\mathrm{ADF}$ & 328 & 47 \\
\hline $\mathrm{FA}$ & 4.2 & 14.2 \\
\hline $\mathrm{C} 16: 0, \%$ of $\mathrm{FA}$ & 36.0 & 32.0 \\
\hline $\mathrm{C} 18: 0, \%$ of $\mathrm{FA}$ & 6.0 & 4.6 \\
\hline $\mathrm{C} 18: 1 \mathrm{n}-9, \%$ of $\mathrm{FA}$ & 6.7 & 36.3 \\
\hline $\mathrm{C} 18: 2 \mathrm{n}-2, \%$ of $\mathrm{FA}$ & 21.2 & 24.7 \\
\hline $\mathrm{C} 18: 3 \mathrm{n}-3, \%$ of $\mathrm{FA}$ & 26.7 & 1.0 \\
\hline
\end{tabular}

animals, due to the greater $\mathrm{C} 18: 3$ content in forage compared with most concentrates (Ryan et al., 2007; Webb and O'Neill, 2008). However, the beneficial effect of a FF system on FA composition is not always clear; Rhee et al. (2000) observed that the intramuscular fat of range goats had more SFA than intramuscular fat from goats fed a grain diet.

Because local demand for Creole goat meat is high in the Caribbean area, different feeding systems were studied to improve its meat production. The growth performance, carcass quality, and noncarcass components of the indigenous Caribbean goats in these feeding systems have been reported in a companion paper (Liméa et al., 2009a). The present study examined the effect of these FF and CF systems on the FA composition of adipose tissues and muscle in Creole kids.

\section{MATERIALS AND METHODS}

The study was conducted on the Experimental Farm of the Institut National de Recherche Agronomique (INRA) Animal Production Research Unit in Guadeloupe and is fully described in Liméa et al. (2009a). All animal care, handling techniques, and slaughter procedures were approved by the INRA Animal Care and Use Committee before the research was initiated.

\section{Experimental Diets and Animals}

Thirty-two male indigenous Caribbean goats (9.0 $\pm 0.2 \mathrm{~kg}$ at $3 \mathrm{mo}$ old) from a total of 40 (Liméa et al., 2009a) were reared in individual pens. Kids were blocked by BW and ADG between 30 and $70 \mathrm{~d}$ preweaning and were randomly assigned to 1 of the 4 groups. Each group (8 replicates per group) received a different diet with a different level of concentrate supplementation. The first group (G0) was fed ad libitum a basal diet exclusively made up of Digitaria decumbens, a green tropical forage, that was cut daily at $28 \mathrm{~d}$ of regrowth. The animals in the other 3 groups $(\mathbf{G 1 0 0}$,
G200, and G300) received daily the same basal diet plus 140,240 , or $340 \mathrm{~g}$ (as fed) of a commercial concentrate, respectively. The concentrate was made up of maize $(68 \%)$, soybean cake $(15 \%)$, and wheat bran (11\%). The chemical and FA composition of forage and concentrate are presented in Table 1.

\section{Slaughtering Procedure}

Animals were slaughtered at a fixed BW of 22 to $24 \mathrm{~kg}$. They were weighed and fasted the day before slaughter. The slaughtering procedures followed the methods standardized by Colomer-Rocher et al. (1987). The omental fat (OF) was removed and weighed. Dressed carcasses were weighed within $1 \mathrm{~h}$ of slaughter (HCW) and after chilling for $24 \mathrm{~h}$ at $4^{\circ} \mathrm{C}$ (cold carcass weight). The perirenal fat (PR) was removed, weighed, sampled, and frozen at $-30^{\circ} \mathrm{C}$. The left shoulder was separated from the cold carcass for dissection and analysis (see Liméa et al., 2009a), and samples of muscle (supraspinatus, SS) and intermuscular adipose (IM) tissues were removed and frozen at $-30^{\circ} \mathrm{C}$ until chemical analysis was done.

\section{Chemical Analysis}

Samples of forage (2 subsamples of $200 \mathrm{~g}$ ) were taken each day from Monday to Friday. One of the subsamples was kept for daily DM determination. All the samples of the feed collected during 2 wk were mixed together for each kid, and a pooled subsample (200 g) was used for chemical analyses. Feed chemical analysis procedures were described in Liméa et al. (2009a). The DM content of PR, IM, and SS was determined after 48 $\mathrm{h}$ of freeze-drying. The lipid extract content of feed and tissues were determined by ether-petroleum extraction (AOAC, 1997). Feed and tissue FA extractions were carried out according to Bas et al. (2003) and Rule (1997) respectively, using tricosanoic acid as an internal standard in the extraction solvent mixture. Feed and 
tissue methylations were described by Bas et al. (2007). Samples were then injected using an auto sampler CP8410 into a Varian CP-3900 gas liquid chromatograph (GLC, Varian, Les Ulis, France) on a DB-wax fusedsilica capillary column $(60 \mathrm{~m}$ length $\times 0.25 \mathrm{~mm}$ i.d. $\times$ $0.25 \mu \mathrm{m}$ film thickness; JW, Folsom, CA). For the GLC procedure, the split/splitless injector, type 1177, and the flame-ionization detector were held at $250^{\circ} \mathrm{C}$. The oven temperature was increased from 120 to $195^{\circ} \mathrm{C}$ at $4^{\circ} \mathrm{C} / \mathrm{min}$ and then held for $60 \mathrm{~min}$ at constant temperature. The injector was in splitless mode for $1.0 \mathrm{~min}$ and then in split mode until the end of the run with a split ratio of 30:1. The column flow rate was $1.2 \mathrm{~mL} / \mathrm{min}$ of He. Fatty acids were identified by comparison with retention time of reference standards (Sigma, St. Louis, MO; Interchim, Montlucon, France) analyzed under similar conditions and integrated using the Star Chromatography Workstation System (version 4.5, Varian Associates Inc., Walnut Creek, CA). The quantification of FA methyl esters was based on the internal standard technique.

\section{Calculations and Statistical Analysis}

The FA methyl esters were summed by families according to their structure: even straight-chain SFA $($ ESFA $)=\mathrm{C} 10: 0+\mathrm{C} 12: 0+\mathrm{C} 14: 0+\mathrm{C} 16: 0+\mathrm{C} 18: 0+$ C20:0 + C22:0 + C24:0; odd-numbered straight-chain FA $($ oddFA $)=\mathrm{C} 13: 0+\mathrm{C} 15: 0+\mathrm{C} 17: 0+\mathrm{C} 17: 1 \mathrm{n}-8+$ C19:0 + C21:0; methyl-branched chain FA of the iso and anteiso forms (iso and anteiso FA) $=i s o \mathrm{C} 14: 0$ + isoC15:0 + anteisoC15:0 + isoC16:0 + isoC17:0 + anteisoC17:0; straight-chain MUFA (MUFA) $=$ C14:1 $+\Sigma \mathrm{C} 16: 1(\mathrm{n}-9$ and n-7) $+\Sigma \mathrm{C} 18: 1(\mathrm{n}-7, \mathrm{n}-9$, trans-10) + $\mathrm{C} 17: 1 \mathrm{n}-8+\mathrm{C} 20: 1+\mathrm{C} 22: 1+\mathrm{C} 24: 1 ; \mathrm{n}-3 \mathrm{FA}=\mathrm{C} 18: 3 \mathrm{n}-3$ $+\mathrm{C} 20: 3 \mathrm{n}-3+\mathrm{C} 20: 5 \mathrm{n}-3+\mathrm{C} 22: 5 \mathrm{n}-3+\mathrm{C} 22: 6 \mathrm{n}-3 ; \mathrm{n}-6$ $\mathrm{FA}=\mathrm{C} 18: 2 \mathrm{n}-6+\mathrm{C} 18: 3 \mathrm{n}-6+\mathrm{C} 20: 2 \mathrm{n}-6+\mathrm{C} 20: 3 \mathrm{n}-6+$ C20:4n-6 + C22:4n-6; PUFA $=$ n-3 FA + n-6 FA.
Regressions of the different variables against the actual intake of concentrate were computed using the REG procedure (SAS Inst. Inc., Cary, NC) to test linear and quadratic effects. Significance was defined at $P \leq 0.05$.

\section{RESULTS}

\section{Growth Performance and Carcass Composition}

The growth performance of the 32 kids used for FA composition analyses (Table 2) was not significantly different to the performance of the entire group of 40 kids (Liméa et al., 2009a). Total FA, C16:0, C18:0, and C18:2n-6 intakes (Table 2) increased with increased concentrate supplementation (linear, $P<0.001$ ). The C18:1n-9 intake increased with increased concentrate supplementation (linear, $P<0.001$; quadratic, $P<$ 0.001 ), whereas C18:3n-3 intake was not affected by dietary group. It took animals on the G0 treatment 4 mo longer to reach slaughter weight compared with G300 (400 vs. 275 d, respectively). The ADG increased linearly with amount of concentrate in the diet. Compared with the FF kids, cold carcass weights of $\mathrm{CF}$ kids were greater when concentrate increased, with no difference between G100 and G200 groups. The weight of adipose tissue deposits (OF, PR, and IM) increased linearly with amount of concentrate in the diet; the quadratic term was significant only for PR weight. The SS weight was the least for the G0 group and the greatest for the G300 group.

\section{Changes in Adipose Tissue and Muscle FA Proportions with Diet}

With increased concentrate, the DM content increased (linear and quadratic, $P<0.05$ ) in PR (Table

Table 2. Fatty acid (FA) intakes, performance, and body adiposity of Creole goats fed diets supplemented with 0 (G0), 140 (G100), 240 (G200), or 340 (G300) g of concentrate ( $=8$ per group $)^{1}$

\begin{tabular}{|c|c|c|c|c|c|c|c|}
\hline \multirow[b]{2}{*}{ Item } & \multicolumn{4}{|c|}{ Diet } & \multirow[b]{2}{*}{ SEM } & \multicolumn{2}{|c|}{$P$-value } \\
\hline & G0 & G100 & G200 & G300 & & Linear & Quad \\
\hline \multicolumn{8}{|l|}{ FA intake, $g \cdot d^{-1}$} \\
\hline C16:0 & 0.63 & 1.15 & 1.51 & 1.93 & 0.087 & $<0.0001$ & 0.173 \\
\hline C18:0 & 0.10 & 0.18 & 0.23 & 0.29 & 0.012 & $<0.0001$ & 0.296 \\
\hline C18:1n-9 & 0.11 & 0.76 & 1.19 & 1.63 & 0.101 & $<0.0001$ & $<0.0001$ \\
\hline $\mathrm{C} 18: 2 \mathrm{n}-6$ & 0.37 & 0.78 & 1.07 & 1.38 & 0.067 & $<0.001$ & 0.068 \\
\hline $\mathrm{C} 18: 3 \mathrm{n}-3$ & 0.47 & 0.44 & 0.44 & 0.48 & 0.009 & 0.100 & 0.065 \\
\hline Total FA intake, $\mathrm{g}$ of $\mathrm{DM} \cdot \mathrm{d}^{-1}$ & 1.70 & 3.31 & 4.44 & 5.72 & 0.270 & $<0.0001$ & 0.110 \\
\hline $\mathrm{ADG}, \mathrm{g} \cdot \mathrm{d}^{-1}$ & 42 & 61 & 74 & 85 & 11.0 & $<0.0001$ & 0.144 \\
\hline Age at slaughter, d & 400 & 334 & 287 & 275 & 8.0 & $<0.0001$ & 0.090 \\
\hline LWS, kg & 22.5 & 23.7 & 22.4 & 23.4 & 1.80 & 0.117 & 0.603 \\
\hline Cold carcass weight, $\mathrm{kg}$ & 9.0 & 10.7 & 11.1 & 11.6 & 0.80 & $<0.0001$ & 0.549 \\
\hline Omental fat, $g$ & 190 & 225 & 319 & 454 & 106.0 & 0.0021 & 0.0603 \\
\hline Perirenal fat, $g$ & 113 & 139 & 255 & 253 & 83.0 & 0.0046 & 0.0054 \\
\hline Intermuscular fat, $\mathrm{g}$ & 51 & 55 & 74 & 91 & 4.4 & 0.0013 & 0.058 \\
\hline Supraspinatus muscle, g & 62 & 79 & 79 & 84 & 1.9 & $<0.0001$ & 0.342 \\
\hline
\end{tabular}

${ }^{1}$ Quad $=$ quadratic; LWS $=$ BW at slaughter. 
Table 3. Fatty acid (FA) composition of the perirenal adipose tissue of Creole goats fed diets supplemented with 0 (G0), 140 (G100), 240 (G200), or 340 (G300) g of concentrate ( $\mathrm{n}=8$ per group $)^{1}$

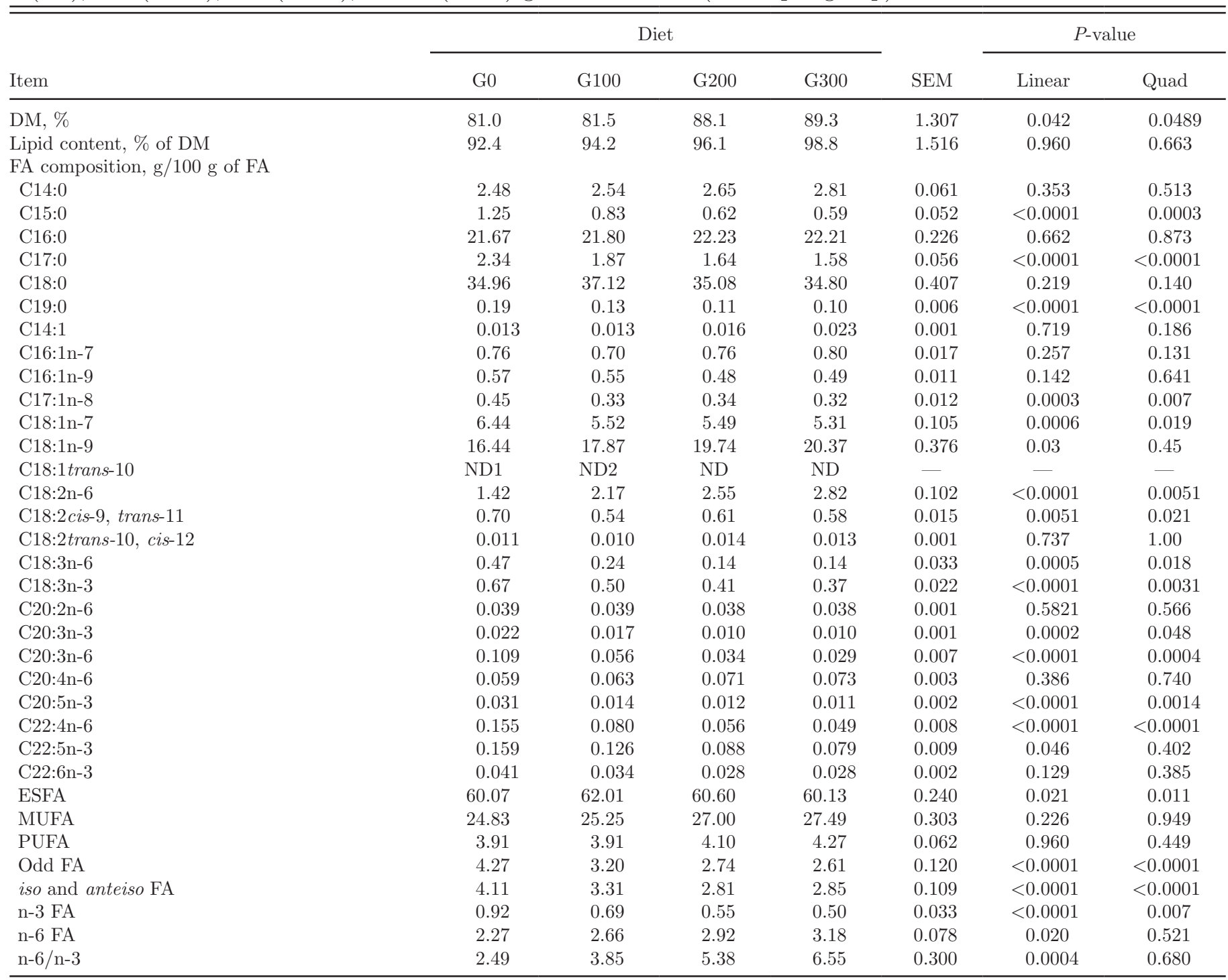

${ }^{1} \mathrm{Quad}=$ quadratic $; \mathrm{ESFA}=$ even straight-chain SFA; odd FA $=\mathrm{C} 13: 0+\mathrm{C} 15: 0+\mathrm{C} 17: 0+\mathrm{C} 17: 1 \mathrm{n}-8+\mathrm{C} 19: 0+\mathrm{C} 21: 0 ;$ iso and anteiso FA $=$ $i s o \mathrm{C} 14: 0+i s o \mathrm{C} 15: 0+$ anteisoC15:0 $+i s o \mathrm{C} 16: 0+i s o \mathrm{C} 17: 0+$ anteisoC17:0; $\mathrm{n}-6 \mathrm{FA}=\mathrm{C} 18: 2 \mathrm{n}-6+\mathrm{C} 18: 3 \mathrm{n}-6+\mathrm{C} 20: 2 \mathrm{n}-6+\mathrm{C} 20: 3 \mathrm{n}-6+\mathrm{C} 20: 4 \mathrm{n}-6$ $+\mathrm{C} 22: 4 \mathrm{n}-6 ; \mathrm{n}-3 \mathrm{FA}=\mathrm{C} 18: 3 \mathrm{n}-3+\mathrm{C} 20: 3 \mathrm{n}-3+\mathrm{C} 20: 5 \mathrm{n}-3+\mathrm{C} 22: 5 \mathrm{n}-3+\mathrm{C} 22: 6 \mathrm{n}-3 ; \mathrm{ND}=$ not detected; ND1 = not detected except 1 kid in group $\mathrm{G} 0$ value $=0.14 \mathrm{~g} / 100 \mathrm{~g}$ of FA; ND2 $=$ not detected except $1 \mathrm{kid}$ in group G100 value $=0.30 \mathrm{~g} / 100 \mathrm{~g}$ of FA.

3) and decreased in SS (linear, $P<0.05)$. The change in DM content of IM was curvilinear (quadratic, $P<$ 0 0.05, Table 4). The lipid content of PR, IM, and SS was not significantly affected by the different levels of concentrate supplementation.

Individual C14:0, C16:0, and C18:0 proportions were not affected by the different amounts of concentrate supplementation in PR, IM, and SS (Tables 3, 4, and 5); neither were total ESFA proportions in IM and SS. However, ESFA proportion in $\mathrm{PR}$ was greater in the G100 group (linear, $P<0.05$; quadratic, $P<0.01$ ) than in the other groups. Total oddFA, C15:0, C17:0, and C19:0, as well as iso- and anteiso-FA proportions in PR, IM, and SS decreased (linear, $P<0.001$; quadratic $P<0.001$ ) with the greatest proportions being for the G0 group and the least for the G200 and G300 groups.
Total MUFA proportions were not affected by the different concentrate supplementation in PR, IM, and SS. Among MUFA, C16:1n-9 proportion was not affected by diets in PR and SS whereas it decreased linearly $(P$ $<0.05)$ in IM with increased concentrate supplementation. The proportion of $\mathrm{C} 16: 1 \mathrm{n}-7$ decreased $(P<0.02)$ linearly with increased concentrate supplementation in SS, whereas it was not modified in PR and IM. The proportion of C17:1n-8 decreased (linear, $P<0.0001$; quadratic $P<0.01$ ) with increased concentrate supplementation in PR and SS, whereas it was not affected by diet in IM. The proportion of $\mathrm{C} 18: 1 \mathrm{n}-9$ increased linearly $(P<0.05)$ with increased concentrate supplementation in PR and IM, whereas it was not affected in SS. The proportion of C18:1n-7 decreased in PR, IM, and SS with increased concentrate supplementation. This effect was quadratic in PR $(P<0.05)$ and SS $(P$ 
Table 4. Fatty acid (FA) composition of the intermuscular adipose tissue of Creole goats fed diets supplemented with 0 (G0), 140 (G100), 240 (G200), or 340 (G300) g of concentrate ( $\mathrm{n}=8$ per group $)^{1}$

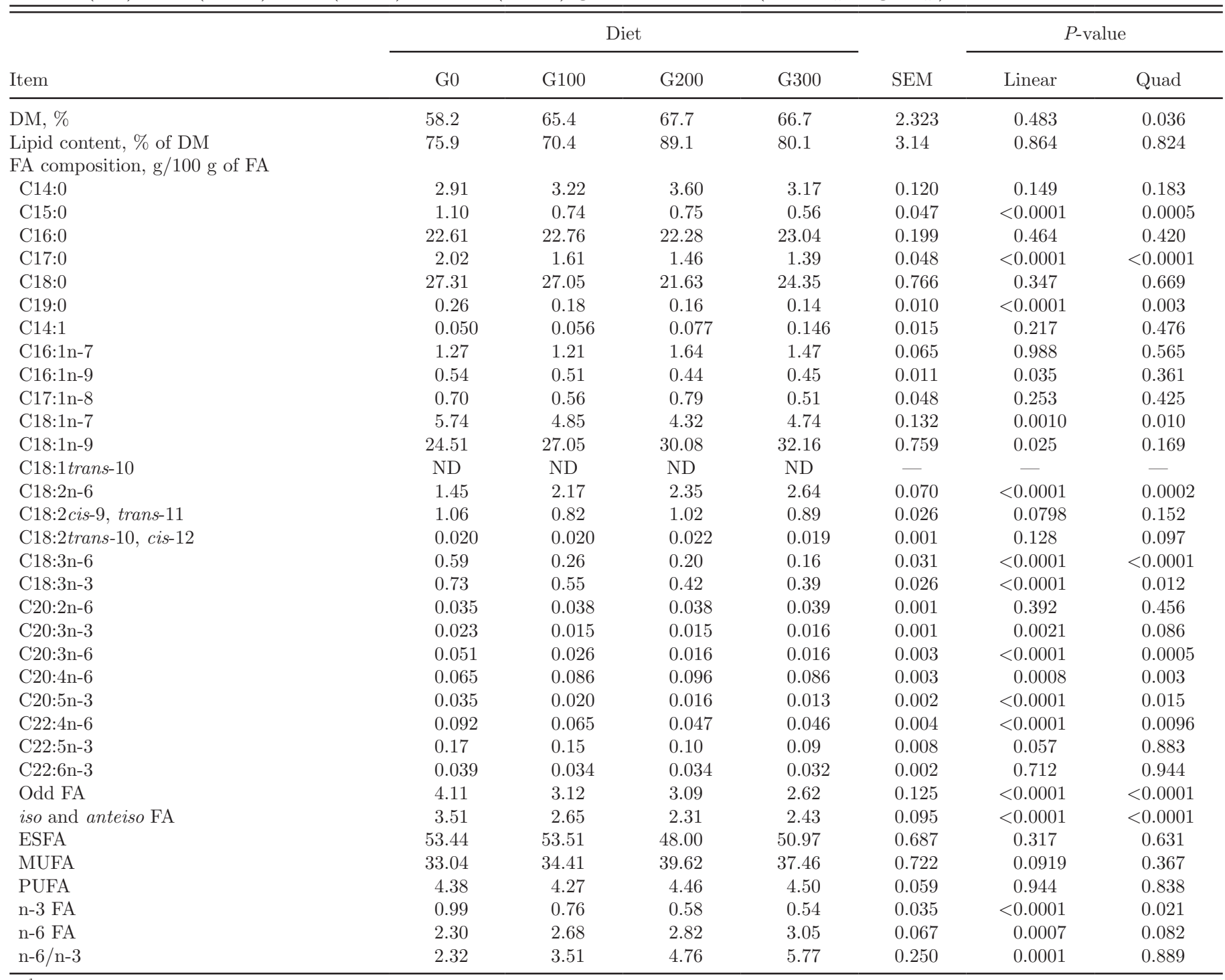

${ }^{1}$ Quad $=$ quadratic $;$ ESFA $=$ even straight-chain SFA; odd FA $=\mathrm{C} 13: 0+\mathrm{C} 15: 0+\mathrm{C} 17: 0+\mathrm{C} 17: 1 \mathrm{n}-8+\mathrm{C} 19: 0+\mathrm{C} 21: 0 ;$ iso and anteiso FA $=$ $i s o \mathrm{C} 14: 0+i s o \mathrm{C} 15: 0+$ anteisoC15:0 + isoC16:0 + isoC17:0 + anteisoC17:0; n-6 FA $=\mathrm{C} 18: 2 \mathrm{n}-6+\mathrm{C} 18: 3 \mathrm{n}-6+\mathrm{C} 20: 2 \mathrm{n}-6+\mathrm{C} 20: 3 \mathrm{n}-6+\mathrm{C} 20: 4 \mathrm{n}-6$ $+\mathrm{C} 22: 4 \mathrm{n}-6 ; \mathrm{n}-3 \mathrm{FA}=\mathrm{C} 18: 3 \mathrm{n}-3+\mathrm{C} 20: 3 \mathrm{n}-3+\mathrm{C} 20: 5 \mathrm{n}-3+\mathrm{C} 22: 5 \mathrm{n}-3+\mathrm{C} 22: 6 \mathrm{n}-3 ; \mathrm{ND}=$ not detected.

$<0.01)$. The C18:1trans-10 was only detected in 1 SS sample, in 2 PR samples, and not at all in IM samples.

The proportions of $\mathrm{C} 18: 2 \mathrm{n}-6$ and total n- 6 FA increased in PR and IM (linear, $P<0.001$ ) with increased concentrate supplementation, with the least proportion being for the G0 group and the greatest for the G300 group. In SS, C18:2n-6 and total n-6 FA proportions increased as concentrate supplementation increased from 0 to $140 \mathrm{~g}$ (G100) and did not change between G100 and G300 groups (linear, $P<0.001$; quadratic, $P<0.05$ ). The proportions of $\mathrm{C} 18: 3 \mathrm{n}-6$ and C22:4n-6 decreased as concentrate supplementation increased from 0 to $240 \mathrm{~g}$ (G200), and remained the same between G200 and G300 groups in all tissues (linear, $P<0.001$; quadratic, $P<0.05)$ except for $\mathrm{C} 22: 4 \mathrm{n}-6$ in SS, which increased from 0 to $240 \mathrm{~g}$ (G200). The proportion of C20:4n-6 increased between G0 and G100 groups in IM and SS but not in PR. The proportions of
C20:3n-6 increased in SS (linear, $P<0.001$; quadratic, $P<0.05$ ) but decreased (linear, $P<0.001$; quadratic, $P<0.001)$ in IM and PR, as concentrate supplementation increased from 0 to $140 \mathrm{~g}$ (G100) and remained the same between G100 and G300 groups. The C20:2n-6 was not affected by diets in the 3 tissues studied. The proportion of C18:2cis-9, trans-11 decreased in PR and SS as concentrate supplementation increased from 0 to 140 g (G100; linear, $P<0.001$; quadratic $P<0.05)$ but remained unchanged in IM.

Total n-3 FA, C18:3n-3, and C20:5n-3 proportions in PR, IM, and SS decreased with increased concentrate supplementation with the greatest proportions being for the G0 group and the least for the G200 and G300 groups (linear, $P<0.001$; quadratic, $P<0.01$ ). The proportion of $\mathrm{C} 22: 5 \mathrm{n}-3$ decreased linearly with increased concentrate supplementation, whereas the C22:6n-3 proportion was not affected in PR, IM, and 
Table 5. Fatty acid (FA) composition of the supraspinatus muscle of Creole goats fed diets supplemented with 0 (G0), 140 (G100), 240 (G200), or 340 (G300) g of concentrate (n = 8 per group) ${ }^{1}$

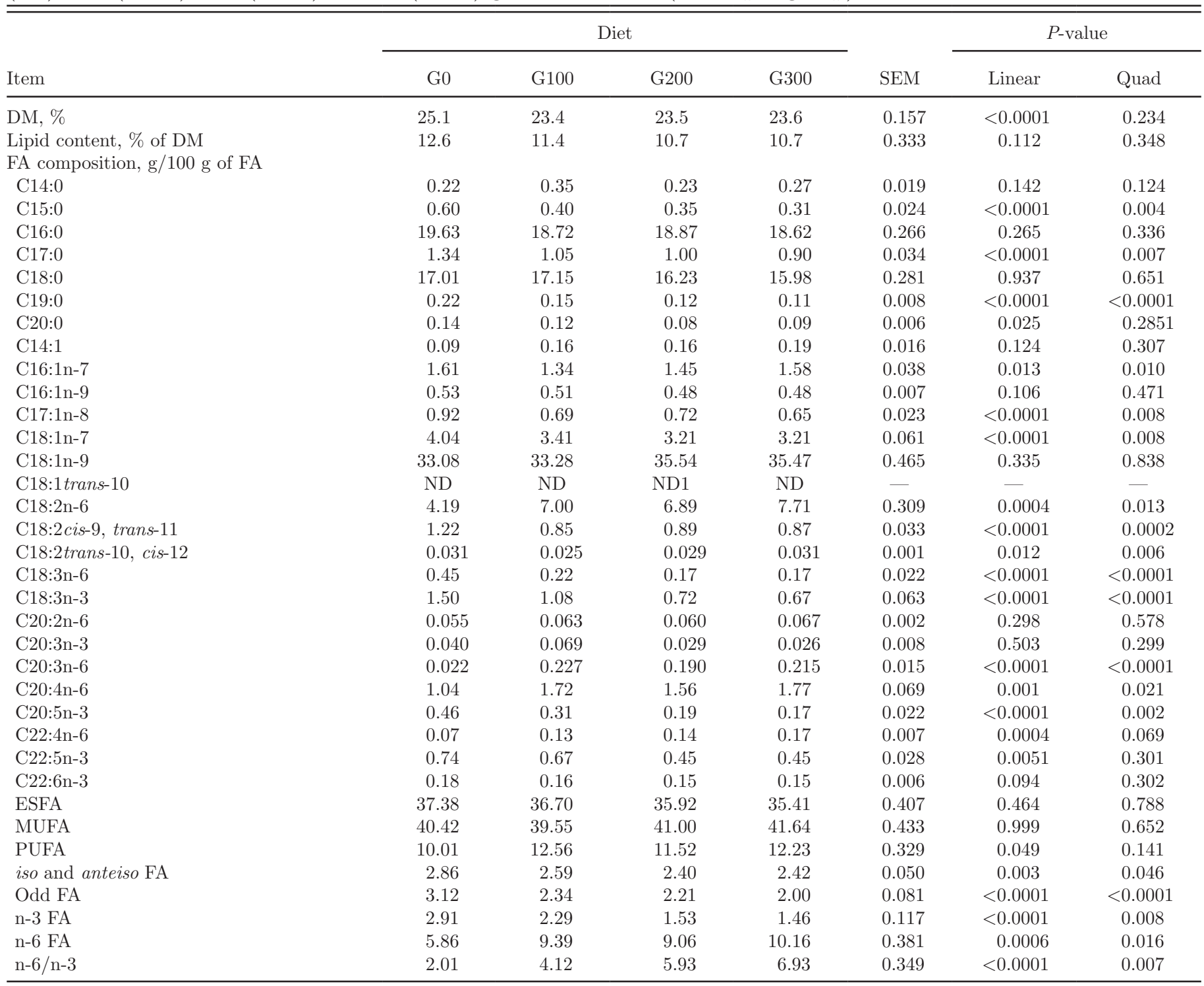

${ }^{1}$ Quad $=$ quadratic ESFA $=$ even straight-chain SFA; odd FA $=$ C13:0 + C15:0 + C17:0 + C17:1n-8 + C19:0 + C21:0; iso and anteiso FA = $i s o \mathrm{C} 14: 0+i s o \mathrm{C} 15: 0+$ anteisoC15:0 + isoC16:0 + isoC17:0 + anteisoC17:0; n-6 FA = C18:2n-6 + C18:3n-6 + C20:2n-6 + C20:3n-6 + C20:4n-6 $+\mathrm{C} 22: 4 \mathrm{n}-6 ; \mathrm{n}-3 \mathrm{FA}=\mathrm{C} 18: 3 \mathrm{n}-3+\mathrm{C} 20: 3 \mathrm{n}-3+\mathrm{C} 20: 5 \mathrm{n}-3+\mathrm{C} 22: 5 \mathrm{n}-3+\mathrm{C} 22: 6 \mathrm{n}-3 ; \mathrm{ND}=$ not detected; ND1 = not detected except 1 kid in group $\mathrm{G} 200$ value $=0.17 \mathrm{~g} / 100 \mathrm{~g}$.

SS. With increased concentrate supplementation, the n-6/n-3 ratio increased linearly $(P<0.001)$ in PR and IM. This effect was quadratic $(P<0.01)$ in SS.

\section{DISCUSSION}

\section{Growth Performance and Carcass Composition}

The aim of this study was to quantify the growth performance, body composition, and the changes in FA profiles of different tissues from goat carcasses fed increasing amounts of concentrate and slaughtered at a fixed commercial BW. Consequently, and by design, the goats fed increased concentrate had a younger slaughter age because they had a greater growth rate due to the greater daily energy intake. The daily $\mathrm{NE}_{\mathrm{g}}$ intake increased from $120 \mathrm{MJ} \cdot \mathrm{d}^{-1}$ (group G0) to $250 \mathrm{MJ} \cdot \mathrm{d}^{-1}$ (group G300), and the ADG ranged from 42 to 85 $\mathrm{g} \cdot \mathrm{d}^{-1}$. Feeding greater amounts of concentrate increased the carcass weight and the dressing percentage in our study (see companion paper, Liméa et al., 2009a). This was in agreement with studies in local goats in which the animals were slaughtered at a fixed age (Atti et al., 2006; Ryan et al., 2007) or at a fixed BW (Bas et al., 2005; Lee et al., 2008). This could be related to a greater muscle development associated with greater energy and protein intakes, as indicated by the greater weight of SS in the carcass of goats fed increased concentrate in this study, and as observed in our previous study on Creole goats (Liméa et al., 2009b). In association with the greater growth rate and energy intake, 
OF, IM, and PR weights were at least doubled between G0 and G300 goats. A similar increase in body fat with increased concentrate supplementation was observed in goats slaughtered at fixed BW (Bas et al., 2005) or at a fixed age (Atti et al., 2006; Ryan et al., 2007), indicating that after partition of energy toward carcass muscle deposition, excess dietary energy was channeled toward lipid deposition, at least in adipose tissues. This was confirmed in the present study (Liméa et al., 2009a). However, lipid proportion in muscle was not affected by level of concentrate because goats fed the all forage-diet had the greatest lipid content in SS, which confirms that lipid deposition in goats is mainly internal (Sahlu et al., 2004), as observed in the companion paper (Liméa et al., 2009a). This study demonstrated that, in the Creole goat breed, feeding increased concentrates increased growth rate and carcass fat content.

In the present paper, FA intake was reduced compared with the lipid intakes (based on ether extract analysis) presented in the companion paper (Liméa et al., 2009a). This was due to the decreased FA content measured in the forage (Table 1).

\section{Overall FA Composition of Adipose Tissues and Muscle of Creole Kids}

In the present study, DM of SS was in agreement with data reported on muscles of goats fed hay (Lee et al., 2008), hay and concentrate (Mahgoub et al., 2002), argan pulp (Bas et al., 2005), or grazed grass supplemented with concentrate (Werdi Pratiwi et al., 2007). However, the Creole goat kids had greater SS lipid content (11 to $13 \%$ of DM) compared with most reported data: 5 to $6 \%$ of muscle DM reported by Werdi Pratiwi et al. (2007) and Lee et al. (2008), and 7 to $9 \%$ reported by Bas et al. (2005) and Atti et al. (2006). Only Mahgoub et al. (2002) reported a greater lipid content (20\% of DM in goats around $20 \mathrm{~kg}$ of BW) compared with our study. Such variations are related to differences in the age and breed of goats studied, as well as to feeding level and energy density of diets (Wood et al., 2008). Moreover, muscle differences (mostly LM vs. SS in the present trial) and differences in fat trimming procedures may also be responsible for these differences (Bas et al., 2005). In the present study, the DM and lipid content of PR were in the high range of reported measurements in goats (Banskalieva et al., 2000; Mahgoub et al., 2002; Bas et al., 2005; Werdi Pratiwi et al., 2007). To our knowledge, few data are available on IM, for comparison.

The G0 goats had similar ESFA proportions in IM and PR adipose tissues (between 50 and $60 \%$ of total FA) but proportions below $40 \%$ in SS. These proportions are in agreement with data in goats fed argan pulp (Bas et al., 2005), but slightly less than those in muscle and adipose tissues of goats fed concentrate and hay (Mahgoub et al., 2002), browse-based diet (Ryan et al., 2007), or grazed grass supplemented with concentrate (Werdi Pratiwi et al., 2007). In this study, C18:0 was the predominant FA in PR, whereas, in SS and IM, C16:0 and C18:0 were in similar proportions. In goats fed concentrate and hay, C16:0 was greater than C18:0 in the muscle (Mahgoub et al., 2002; Ryan et al., 2007; Werdi Pratiwi et al., 2007) but in similar proportions in PR (Mahgoub et al., 2002). However, goats fed argan pulp had similar proportions of C16:0 and C18:0 in both PR and muscle (Bas et al., 2005). In all studied tissues of the Creole goats and especially in SS, the C14:0 proportion was reduced, and less than most of the published values (Mahgoub et al., 2002; Bas et al., 2005; Atti et al., 2006; Werdi Pratiwi et al., 2004, 2007). Because consumption of $\mathrm{C} 14: 0$ has been implicated in increasing plasma cholesterol, meat from indigenous Caribbean goats with its reduced C14:0 may have positive health implications.

In our Creole goats, the proportions of n-3 FA were classically greater in the muscle than in the adipose tissues because muscle has a greater phospholipid content than adipose tissues, phospholipids that are characterized by greater 18:3n-3 and n-3 FA proportions than storage lipids (Wood et al., 2008). The most represented FA in all studied tissues was 18:3n-3, but the most biologically significant FA are C20:5n-3, C22:5n-3, and C22:6n-3 when dietary recommendations for human health are considered (Wood et al., 2008). From this point of view, total n-3 FA in muscle and PR were in the range observed in goats fed argan pulp (Bas et al., 2005 ), but less than those observed in muscle of goats fed a browse diet (Ryan et al., 2007). Differences in n-3 FA proportions between these experiments may be related to differences in the C18:3 content of experimental diets, as well as in ruminal physico-chemical conditions that affect ruminal biohydrogenation of PUFA (Glasser et al., 2008). Data on C20:5n-3, C22:5n-3, and C22:6n-3 are scarce for goat muscle and adipose tissues (Lee et al., 2008).

Proportions of n-6 FA in edible tissues are usually greater than those of n- $3 \mathrm{FA}$, as dietary $\mathrm{C} 18: 2 \mathrm{n}-6$ is less biohydrogenated than dietary C18:3n-3 (Glasser et al., 2008), and as C18:2n-6 and its long-chain products C20:4n-6 and C22:4n-6 are preferentially deposited in phospholipids compared with n-3 FA (Wood et al., 2008). Total n-6 FA, C20:4n-6, and C22:4n-6 proportions in muscle and $\mathrm{PR}$ of our Creole goats were less than those reported by Bas et al. (2005), but were in the range of those reported for C18:2n-6 in muscle and PR (Mahgoub et al., 2002; Lee et al., 2008). With respect to $\mathrm{n}-3 \mathrm{FA}$, these results may be explained by differences in dietary C18:2 intake and conditions of ruminal biohydrogenation.

Trans-FA in goat muscle or in adipose tissues have been scarcely reported in the literature, especially for the profile of trans-C18:1 FA. In our study, only C18:1trans-10 can be quantified, C18:1cis-11 and C18:1trans-11 co-elute on the DB-Wax column used (Kramer et al., 2002; Alves and Bessa, 2009) and cannot be quantified separately. Other positional isomers of C18:1trans FA in muscle or adipose tissues cannot 
be obtained because they are not well separated from each other. Under these conditions, C18:1trans-10 was never detected in SS or in IM from G0 goats, and only 1 goat fed this diet exhibited a value above the threshold of sensitivity of our method in the PR tissue. In goats fed the all-forage diet, these results are consistent with the fact that $\mathrm{C} 18: 1$ trans-10 mainly reflects changes in the ruminal biohydrogenation process of FA associated with changes in $\mathrm{pH}$ and microbial populations (Harfoot and Hazlewood, 1997; Jenkins et al., 2008) induced by feeding high-grain diets, for example in lambs (Bas et al., 2007). This is confirmed by the very low concentration of the trans-10, cis-12 isomer of the CLA (0.01 to 0.03 in the muscle or in the adipose tissues) that is generally produced when high-grain diets are fed. The proportions of $\mathrm{C} 18: 2$ cis- 9 , trans-11 were in the greater range of values reported in lambs (Bas et al., 2007).

The proportions of C18:1n-9 tended to be less than in other studies on growing goats (Casey and Van Niekerk, 1985; Mahgoub et al., 2002; Dhanda et al., 2003; Werdi Pratiwi et al., 2004). The total oddFA plus iso- and anteiso-FA proportions ranged from 4.4 to $8.4 \%$ of the total FA in all tissues with progressively increased proportions in SS, IM, and PR, respectively. These results are in the greater range of what is usually observed but agreed with results of Bas et al. (2005) in young Morocco goats in semi-intensive conditions.

\section{Effect of Increased Concentrate Supplementation on FA Composition of Adipose Tissues and Muscle in Creole Goats}

In this experiment, increased concentrate supplementation significantly increased the DM content of PR and tended to increase the DM content of IM, with only small changes in their lipid content. This could be due to a faster growth of adipocyte size for these younger goats at greater energy intakes. Conversely, increased concentrate supplementation slightly decreased the DM and lipid contents of SS. This is in contrast to several studies that have reported greater DM and muscle fat contents in goats (Bas et al., 2005; Lee et al., 2008) or in lambs (Bas et al., 2007) fed increased concentrate. Nevertheless, some studies also reported no changes in DM or in lipid contents of muscle of goats fed different levels of concentrate (Atti et al., 2006). The discrepancy between this study and others could be explained by the type of muscle studied (LM in most experiments vs. SS in our study) but also by the younger age of the goats fed concentrate. For instance, Mahgoub et al. (2002) and Werdi Pratiwi et al. (2007) reported that DM or lipid contents in adipose tissue or in muscle increased with increased age of growing goats (increased BW).

Increased concentrate supplementation did not increase the proportions of $\mathrm{C} 14: 0$ and $\mathrm{C} 16: 0$ in PR, IM, and SS, which is desirable for human nutrition (Micha and Mozaffarian, 2010). Moreover, it did not affect
C18:0 and ESFA proportions in IM and SS, although in PR there was a small (maximal $2 \%$ ) increase in the G100 group compared with the average proportion of ESFA (60\%) observed in the other experimental groups. Increased concentrate supplementation has given rise to inconsistent results in the literature. Proportions of ESFA, C14:0, C16:0, and C18:0 were not affected by concentrate levels in IM lipids of goats (Atti et al., 2006; Lee et al., 2008), whereas these FA were greatly increased in the muscle of goats fed increasing percentages of concentrate (Ryan et al., 2007), or decreased in the muscle of grain-fed goats compared with range goats (Rhee et al., 2000). Moreover, these FA could be differently affected according to the tissue considered, as observed by Bas et al. (2005). This author reported only small changes in C14:0 and C16:0 but a decrease of C18:0 and ESFA proportions in muscle, but not in PR tissue, of goats fed argan pulp with increased percentage of concentrate. Because part of the C16:0 and most of the C18:0 in adipose tissue and muscle arise from dietary FA, differences among experiments may reflect differences in FA intake, differences in PUFA intake, as well as differences in ruminal biohydrogenation of the PUFA and transfer into the tissues being considered (Geay et al., 2001). Moreover, differences may also be due to the preweaning diet (milk FA composition), especially for C14:0, because FA of body fat stored before weaning influenced the FA composition of fat deposits and muscle several months after weaning (Bas and Morand-Fehr, 2000). However, all these data suggest that feeding concentrate has little, if any, effect on SFA proportions in edible parts of goat meat.

The C15:0, C17:0, and C19:0 proportions as well as iso- and anteiso- FA proportions decreased with increased concentrate level in all studied tissues, the PR being the most affected and SS being the least affected. These results are in agreement with a decrease in oddFA and methyl branched-chain FA proportions observed with increased concentrate level in most studies in goats (Bas et al., 2005; Lee et al., 2008), but not in all studies (Atti et al., 2006; Ryan et al., 2007). This probably reflects the decrease of microbial synthesis of FA in the rumen as these FA mainly originate from ruminal lipid microbial synthesis (Vlaeminck et al., 2006), especially when diets have increased NDF contents (Bas et al., 2003). With regard to health aspects, the decrease in oddFA can be considered as neutral because these FA are not known to have any effect on health.

In the present experiment, the commercial concentrate was rich in C18:2n-6 due to the components used (corn and soybean cake), and as stated above, greater intakes of C18:2n-6 were observed in goats fed increased concentrate supplementation. Despite extensive ruminal hydrogenation of $\mathrm{C} 18: 2 \mathrm{n}-6$ in the rumen (on average 90\%, Glasser et al., 2008), the differences in the proportions of $\mathrm{C} 18: 2 \mathrm{n}-6$ in the studied tissues reflected the changes in its dietary intake. Surprisingly, the C18:3n-3 intake was not different between groups. 
This was due to the rather low $\mathrm{C} 18: 3$ content of the forage $\left(1.1 \mathrm{~g} \cdot \mathrm{kg}^{-1}\right.$ of DM) and to the only slight decrease of forage intake when concentrate was fed (maximum $-50 \mathrm{~g} \cdot \mathrm{d}^{-1}$, which means $-55 \mathrm{mg}$ of $\left.\mathrm{C} 18: 3 \cdot \mathrm{d}^{-1}\right)$. This slight decrease was compensated by the C18:3 from concentrate intake. Generally, goats fed grass pasture or forage had greater C18:3n-3 proportions in fat deposits and muscle than animals fed concentrate baseddiets when these concentrates are poor in C18:3n-3 (Bas et al., 2005; Lee et al., 2008). This was not the case when concentrates were rich in C18:3 (Bas et al., 2007), which reflected a positive relationship between intake of C18:3n-3 and its proportion in meat (Wood et al., 2008). In our study, the goats fed the forage diet had slightly greater C18:3n-3 proportions in all studied tissues, despite a similar intake when compared with the concentrate fed-groups. This may have been due to a reduction in C18:3n-3 ruminal biohydrogenation (95\% on average, Glasser et al., 2008) in the rumen of goats fed $D$. decumbens by a mechanism that remains to be elucidated or a dilution effect caused by the absorbed C18:3n-3 being distributed in a greater amount of lipid in the kids fed concentrates (this assumes that duodenal flows of C18:3n-3 remained the same between groups).

The decrease in 18:3n-3 proportions with increased level of concentrate supplementation was associated with decreased proportions of the different n-3 FA (C20:3n-3, C20:5n-3, and C22:5n-3, but not for the $\mathrm{C} 22: 6 \mathrm{n}-3)$ in all studied tissues. The increase in C18:2n-6 proportions with increased concentrate supplementation were also associated with an increase in C20:4n-6 in IM and SS but not in PR. All these results are in line with previous results on long-chain PUFA in tissues of goats or lambs fed diets with increased C18:2/C18:3 intake (Aurousseau et al., 2004; Bas et al., 2005, 2007; Ryan et al., 2007; Lee et al., 2008). Therefore the n-6/n-3 ratio significantly increased in PR, IM, and SS from G0 to G300. With regard to the recommendation of a $\mathrm{n}-6 / \mathrm{n}-3$ ratio below 4 (Wood et al., 2008) to improve the nutritional value of meat, the most favorable meat based on the ratio in IM and SS was that produced from Creole goats fed 0 to $140 \mathrm{~g}$ of commercial concentrate.

The proportions of C18:2cis-9, trans-11 were greater in forage-fed goats than concentrate-fed goats in PR and SS. This agrees with results obtained on muscles of lambs fed grass or concentrate (Nuernberg et al., 2005; Aurousseau et al., 2007). Similar results were reported in steers fed increased concentrate on grassbased diets (French et al., 2000); they were related to a decrease in the C18:1trans-11-producing bacteria at a similar C18:2n-6 intake (French et al., 2000). Factors that determine the amount of cis-9, trans-11 C18:2 in the tissues are the dietary intake of $\mathrm{C} 18: 2$, the rumen conditions that may affect the growth and activity of C18:1trans-11-producing bacteria (Butyrivibrio fibrisolvens; Klieve et al., 2003), and the $\Delta^{9}$-desaturase enzyme that desaturates $\mathrm{C} 18: 1$ trans-11 to $\mathrm{C} 18: 2$ cis-9, trans-11 C18:2 in the muscular and adipose tissues. Moreover, a C18:2n-6 increase in diet has also been shown to increase the $\mathrm{C} 18: 2$ cis- 9 , trans- 11 proportion in tissues (Beaulieu et al., 2002; Bas et al., 2007). Consequently, an increase in C18:2cis-9, trans-11 proportion in tissues of goats could also have been expected in our study. This was not the case, possibly because of the changes in fermentation patterns associated with high-concentrate diets or because of the dilution of this FA in the greater lipid content of PR and IM on these diets. It has been shown that high-concentrate diets promote the growth of the bacterial strain Megasphera elsdenii with cis-9, trans-10 isomerase activity resulting in C18:1trans-10 production, at the expense of B. fibrisolvens, which has a cis-9, trans-11 isomerase activity (Klieve et al., 2003) resulting in C18:1trans-11 production. However, we failed to detect the C18:1trans-10 in most tissues except in very few goats in our study, which is also in agreement with the absence of variation of C18:2trans-10, cis-12 in all tissues with concentrate supplementation. More probably, limited C18:1trans-11 availability from ruminal fermentation to muscle and adipose tissues may have resulted in a reduced proportion of C18:2cis-9, trans-11 in these tissues in our study. Indeed, we observed a decreased in $\mathrm{C} 18: 1 \mathrm{n}-7$ proportions in all tissues. However, we were unable to distinguish between cis-11 and trans-11 C18:1. Because the C18:1n-7 corresponded to the sum of the C18:1 cis-11 and C18:1trans-11, it is difficult to conclude which FA is involved in that variation. Even though Faucitano et al. (2008) showed that increased dietary concentrate increased the proportion of $\mathrm{C} 18: 1$ cis-11 in the muscle of steers, the greater variation of n-7 observed between groups might be due to the trans- 11 isomer as in PR and muscle C18:1n-7 and C18:2cis-9, trans-11 were positively correlated $(\mathrm{r}=0.545$ in $\mathrm{PR}$ and 0.732 in SS; $P<0.001)$. Consequently, limited availability of C18:1trans-11 may account for the reduced C18:2cis-9, trans-11 proportions in all studied tissues.

The C18:1n-9 proportion in adipose tissues increased with increased concentrate supplementation. This result is in agreement with other studies (Rhee et al., 1997; Bas et al., 2005; Ryan et al., 2007; Faucitano et al., 2008). The C18:1n-9 in tissues originates partly from this FA intake not being completely biohydrogenated in the rumen, and partly from de novo conversion of C18:0 by the $\Delta^{9}$-desaturase enzyme in tissues. In the present study, a significant increase in C18:1n-9 intake was observed with increased concentrate supplementation. The best estimate of this enzyme activity is the $\Delta^{9}$-desaturase activity proxy, which is calculated as ID14 (ID14 = C14:1 cis-9 $\times$ 100/C14:0 + C14:1 cis-9). When calculating the $\Delta^{9}$-desaturase activity proxy, significant increases were observed with increasing intake of concentrate in PR (G0: 0.52; G100: 0.51; G200: 0.63; G300: 0.79) and in IM (G0: 1.72; G100: 1.68; G200: 2.50; G300: 2.44). This therefore suggests that desaturase enzyme activity could have been induced but not completely proportional to levels of concentrate, prob- 
ably in response to an increased desaturase gene expression induced by insulin (Daniel et al., 2004) and downregulated by PUFA (Bas et al., 2005). However, contrary to results from adipose tissues, we failed to show any differences in the C18:1n-9 proportion in SS with increased concentrate supplementation. However, a significant increase of the ID14 proxy with levels of concentrate was measured (G0: 29.5; G100: 27.5; G200: 40.9; G300: 40.6) in muscle.

In this study, the growth performance and FA composition of adipose tissues and muscle from male indigenous Caribbean goats were altered by feeding increased concentrate. This was due to the differences in energy and FA intake, and possibly also to the age of the animals slaughtered at a constant BW. From a nutritional point of view, meat from Creole goats fed the all-forage diet was similar to that of other goat breeds fed similar diets. Increased concentrate supplementation did not affect the proportion of MUFA, increased PUFA in muscle, and had very few effects on ESFA in tissues. One of the major modifications of FA composition was the decrease in n-3 PUFA and increase in n-6 PUFA in all tissues with increased concentrate supplementation. When evaluating the effect of changes in FA composition with regard to human health, concentrate supplementation did not increase any cholesterol-raising SFA in meat, but increased the n- $6 / \mathrm{n}-3$ ratio above 4 when more than $200 \mathrm{~g}$ of concentrate was added to the diet. Therefore, it is recommended to feed concentrates at levels less than $240 \mathrm{~g} / \mathrm{d}$ to have FA compositions that are desired for current human nutrition guidelines.

\section{LITERATURE CITED}

Alves, S. P., and R. J. B. Bessa. 2009. Comparison of two gas-liquid chromatograph columns for the analysis of fatty acids in ruminant meat. J. Chromatogr. A 1216:5130-5139.

AOAC. 1997. Official Methods of Analysis. 16th ed. Assoc. Off. Anal. Chem., Arlington, VA.

Atti, N., M. Mahouachi, and H. Rouissi. 2006. The effect of spineless cactus (Opuntia ficus-indica $f$. inermis) supplementation on growth, carcass, meat quality and fatty acid composition of male goat kids. Meat Sci. 73:229-235.

Aurousseau, B., D. Bauchart, E. Calichon, D. Micol, and A. Priolo. 2004. Effect of grass or concentrate feeding systems and rate of growth on triglyceride and phospholipid and their fatty acids in the $\mathrm{m}$. Longissimus thoracis of lambs. Meat Sci. 66:531-541.

Aurousseau, B., D. Bauchart, A. L. Galot, S. Prache, D. Micol, and A. Priolo. 2007. Indoor fattening of lambs raised on pasture: 2 . Influence of stall finishing duration on triglyceride and phospholipid fatty acids in the Longissimus thoracis muscle. Meat Sci. 76:417-427.

Banskalieva, V., T. Sahlu, and A. L. Goetsch. 2000. Fatty acid composition of goat muscles and fat depots: A review. Small Rumin. Res. 37:255-268.

Bas, P., H. Archimede, A. Rouzeau, and D. Sauvant. 2003. Fatty acid composition of mixed-rumen bacteria: Effect of concentration and type of forage. J. Dairy Sci. 86:2940-2948.

Bas, P., V. Berthelot, E. Pottier, and J. Normand. 2007. Effect of level of linseed on fatty acid composition of muscles and adipose tissues of lambs with emphasis on trans fatty acids. Meat Sci. $77: 678-688$.
Bas, P., E. Dahbi, A. El Aich, P. Morand-Fehr, and A. Araba. 2005. Effect of feeding on fatty acid composition of muscles and adipose tissues in young goats raised in the argan tree forest of Morocco. Meat Sci. 71:317-326.

Bas, P., and P. Morand-Fehr. 2000. Effect of nutritional factors on fatty acid composition of lamb fat deposits. Livest. Prod. Sci. 64:61-79.

Beaulieu, A. D., J. K. Drackley, and N. R. Merchen. 2002. Concentrations of conjugated linoleic acid (cis-9, trans-11-octadecadienoic acid) are not increased in tissue lipids of cattle fed a high-concentrate diet supplemented with soybean oil. J. Anim. Sci. 80:847-861.

Casey, N. H., and W. A. Van Niekerk. 1985. Fatty acid composition of subcutaneous and kidney fat depots of Boer goats and response to varying levels of maize meal. S. Afr. J. Anim. Sci. 15:60-62.

Colomer-Rocher, F., P. Morand-Fehr, and A. H. Kirton. 1987. Standard methods and procedures for goat carcass evaluation, jointing and tissue separation. Livest. Prod. Sci. 17:149-159.

Daniel, Z. C. T. R., R. J. Wynn, A. M. Salter, and P. J. Buttery. 2004. Differing effects of forage and concentrate diets on the oleic acid and conjugated linoleic acid content of sheep tissues: The role of stearoyl-CoA desaturase. J. Anim. Sci. 82:747-758.

Dhanda, J. S., D. G. Taylor, and P. J. Murray. 2003. Part 2. Carcass composition and fatty acid profiles of adipose tissue of male goats: Effects of genotype and liveweight at slaughter. Small Rumin. Res. 50:67-74.

Faucitano, L., P. Y. Chouinard, J. Fortin, I. B. Mandell, C. Lafreniere, C. L. Girard, and R. Berthiaume. 2008. Comparison of alternative beef production systems based on forage finishing or grain-forage diets with or without growth promotants: 2 . Meat quality, fatty acid composition, and overall palatability. J. Anim. Sci. 86:1678-1689.

French, P., C. Stanton, F. Lawless, E. G. O'Riordan, F. J. Monahan, P. J. Caffrey, and A. P. Moloney. 2000. Fatty acid composition, including conjugated linoleic acid, of intramuscular fat from steers offered grazed grass, grass silage or concentrate-based diets. J. Anim. Sci. 78:2849-2855.

Geay, Y., D. Bauchart, J.-F. Hocquette, and J. Culioli. 2001. Effect of nutritional factors on biochemical, structural and metabolic characteristics of muscles in ruminants, consequences on dietetic value and sensorial qualities of meat. Reprod. Nutr. Dev. 41:1-26.

Glasser, F., P. Schmidely, D. Sauvant, and M. Doreau. 2008. Digestion of fatty acids in ruminants: A meta-analysis of flows and variation factors: 2. C18 fatty acids. Animal 2:691-704.

Harfoot, C. G., and G. P. Hazlewood. 1997. Lipid metabolism in the rumen. Pages 382-426 in The Rumen Microbial Ecosystem. P. N. Hobson and C. S. Stewart, ed. Blackie Academic, London, UK.

Jenkins, T. C., R. J. Wallace, P. J. Moate, and E. E. Mosley. 2008. Board-invited review: Recent advances in biohydrogenation of unsaturated fatty acids within the rumen microbial ecosystem. J. Anim. Sci. 86:397-412.

Klieve, A. V., D. Hennessy, D. Ouwerkerk, R. J. Forster, R. I. Mackie, and G. T. Attwood. 2003. Establishing populations of Megasphaera elsdenii YE 34 and Butyrivibrio fibrisolvens YE 44 in the rumen of cattle fed high grain diets. J. Appl. Microbiol. 95:621-630.

Kramer, J. K. G., C. Blackadar, and J. Q. Zhou. 2002. Evaluation of two GC columns (60-m SUPELCOWAX 10 and 100-m CP Sil 88) for analysis of milkfat with emphasis on CLA, 18:1, 18:2 and 18:3 isomers, and short- and long-chain FA. Lipids $37: 823-835$.

Lee, J. H., B. Kouakou, and G. Kannan. 2008. Chemical composition and quality characteristics of chevon from goats fed three different post-weaning diets. Small Rumin. Res. 75:177-184.

Liméa, L., M. Boval, N. Mandonnet, G. Garcia, H. Archimède, and G. Alexandre. 2009a. Fattening performances, carcass quality 
and non-carcass components of indigenous Caribbean goats under varying nutritional densities. J. Anim. Sci. 87:3770-3781.

Liméa, L., J. Gobardham, G. Gravillon, A. Nepos, and G. Alexandre. 2009b. Growth and carcass traits of Creole goats under different pre-weaning, fattening and slaughter conditions. Trop. Anim. Health Prod. 41:61-70.

Mahgoub, O., A. J. Khan, R. S. Al Maqbaly, J. N. Al Sabahi, K. Annamalai, and N. M. Al Sakry. 2002. Fatty acid composition of muscle and fat tissues of Omani Jebel Akhdar goats of different sexes and weights. Meat Sci. 61:381-387.

Micha, R., and D. Mozaffarian. 2010. Saturated fat and cardiometabolic risk factors, coronary heart disease, stroke, and diabetes: A fresh look at the evidence. Lipids 45:893-905.

Nuernberg, K., G. Nuernberg, K. Ender, D. Dannenberger, W. Schabbel, S. Grumbach, W. Zupp, and H. Steinhart. 2005. Effect of grass vs. concentrate feeding on the fatty acid profile of different fat depots in lambs. Eur. J. Lipid Sci. Technol. 107:737-745.

Rhee, K. S., D. F. Waldron, Y. A. Ziprin, and K. C. Rhee. 2000. Fatty acid composition of goat diets vs intramuscular fat. Meat Sci. 54:313-318.

Rhee, K. S., Y. A. Ziprin, C. E. Bishop, and D. F. Waldron. 1997. Composition and stability of goat meat patties as affected by breed type and feeding regimen. J. Food Sci. 62:949-962.

Rule, D. C. 1997. Direct transesterification of total fatty acids of adipose tissue, and of freeze-dried muscle and liver with borontrifluoride in methanol. Meat Sci. 46:23-32.
Ryan, S. M., J. A. Unruh, M. E. Corrigan, J. S. Drouillard, and M. Seyfert. 2007. Effects of concentrate level on carcass traits of Boer crossbred goats. Small Rumin. Res. 73:67-76.

Sahlu, T., A. L. Goetsch, J. Luo, I. V. Nsahlai, J. E. Moore, M. L. Galyean, F. N. Owens, C. L. Ferrell, and Z. B. Johnson. 2004. Nutrient requirements of goats: Developed equations, other considerations and future research to improve them. Small Rumin. Res. 53:191-192.

Vlaeminck, B., V. Fievez, D. Demeyer, and R. J. Dewhurst. 2006. Effect of forage:concentrate ratio on fatty acid composition of rumen bacteria isolated from ruminal and duodenal digesta. J. Dairy Sci. 89:2668-2678.

Webb, E. C., and H. A. O'Neill. 2008. The animal fat paradox and meat quality. Meat Sci. 80:28-36.

Werdi Pratiwi, N. M., P. J. Murray, and D. G. Taylor. 2004. The fatty acid composition of muscle and adipose tissues from entire and castrated male Boer goats raised in Australia. Anim. Sci. 79:221-229

Werdi Pratiwi, N. M., P. J. Murray, and D. G. Taylor. 2007. Feral goats in Australia: A study on the quality and nutritional value of their meat. Meat Sci. 75:168-177.

Wood, J. D., M. Enser, A. V. Fisher, G. R. Nute, P. R. Sheard, R. I. Richardson, S. I. Hughes, and F. M. Whittington. 2008. Fat deposition, fatty acid composition and meat quality: A review. Meat Sci. 78:343-358. 
References

This article cites 37 articles, 6 of which you can access for free at: http://www.journalofanimalscience.org/content/90/2/605\#BIBL 